\title{
ВОПРОС О ВЫДАЧЕ МАТЕРИАЛЬНЫХ ПОСОБИЙ КОМАНДНОМУ СОСТАВУ НИЖЕГОРОДСКОГО ОПОЛЧЕНИЯ ОСЕНЬЮ - ЗИМОЙ 1812 Г.
}

\section{THE ISSUE OF GRANTING MATERIAL ALLOWANCES TO THE COMMAND STAFF OF THE NIZHNY NOVGOROD MILITIA IN THE AUTUMN-WINTER OF 1812.}

D. Nikolaev

F. Dorofeev

Summary: Based on the archival materials of the Central Archive of the Nizhny Novgorod Region (TSANO), this article discusses the issue of granting material allowances to representatives of the command staff of the Nizhny Novgorod militia formed in the era of 1812. On the basis of the office documentation, information is provided on the numerical and personal composition of the recipients of financial assistance, as well as data on the amounts received and some other features of receiving material assistance in the context of the formation of the Nizhny Novgorod militia of 1812.

Keywords: Patriotic War of 1812, Nizhny Novgorod militia in 1812, marching march, weapon, equipment, financial assistance.

\author{
Николаев Дмитрий Андреевич \\ К.и.н., дочент, Нижегородский государственный \\ университет им. Н.И. Лобачевского \\ dmnikolaeff@mail.ru \\ Дорофеев Федор Александрович \\ К.и.н., дочент, Нижегородский государственный \\ университет им. Н.И. Лобачевского
}

feddor70@mail.ru

Аннотация: В данной статье на основе архивных материалов Центрального архива Нижегородской области (ЦАНО) рассматриваются вопросы о выдаче материальных пособий представителям командного состава нижегородского ополчения, формируемого в эпоху 1812 г. На основе делопроизводственной документации приводятся сведения о численном и персональном составе получателей финансовой помощи, а также данные о полученных суммах и некоторых прочих особенностях получения материальной помощи в контексте процесса формирования нижегородского ополчения 1812 г.

Ключевые слова: Отечественная война 1812 г., нижегородское ополчение 1812 г., походный марш, оружие, снаряжение, материальная помощь.

с.98]. Конный полк ополчения возглавил действительный статский советник П.Ф. Козлов [19, с.115]. Среди полномочных структур [15, с.217], созданных специально для этой цели, особо выделялись, по своему значению и функциям, комитеты пожертвований [5, с.95] и вооружения [13, с.58]. Обмундирование [14, с.58], снаряжение $[12$, с.39] и даже вооружение $[10$, с.75] ополчений той поры осуществлялось за счет «отдатчиков ратников», т.е. помещиков [11, с.345], либо мещанских сообществ [16, с.35]. Все полки нижегородского ополчения входили в состав так называемого III ополченского округа (вместе с ополчениями казанским, вятским, симбирским, пензенским и костромским) [7, с.368] под предводительством генерал-лейтенанта П.А. Толстого [8, с.67]; начальником же нижегородского ополчения являлся князь Г.А. Грузинский.

В ходе сбора ополчения сразу же обозначилась проблема малоимущих потенциальных офицеров, которые были не в состоянии обеспечить себя всем необходимым за свой собственный счет (как это изначально предписывалось для всех офицеров ополчения). По соглашению с Толстым, учитывая рапорты командиров всех, без исключения, полков ополчения, в которых содержались 
просьбы о выдаче пособий многочисленной когорте офицеров, которые «не имеют средств себя содержать» и «терпят крайнюю нужду» [20], командованием ополчения, «для пользы службы», было решено сделать «единовременное денежное вспомоществование неимущим чиновникам» (т.е. офицерам - авт.) ... из сумм, в пожертвование взнесенной на обмундирование их приличное обер-офицерам, подобно (тому - авт.) как сделана (была - авт.) таковая же помощь и из суммы дворянской неимущим дворянам, для чего, по самому умеренному расчислению вещей полагается на каждого такового чиновника по 100 рублей ... предложен всем таковым чиновникам именной список, по которому требуется произвесть выдачу 32 чиновникам 3200 руб.» [22, л.1].

Согласно «Списку недостаточным чиновникам, вступившим во внутреннее нижегородское ополчение» [22], материальное пособие в сентябре 1812 г. получили 32 чел. [22, л.9] (из всех ополченских полков). В начале октября 1812 г. материальное пособие двумя «траншами» получили две «партии» (в 20 и 14 чел.) «недостаточных офицеров» ополчения [22, л.18]. Несколько позднее руководством нижегородского ополчения было принято решение об оказании финансовой помощи также и «прапорщикам, портупей-прапорщикам и урядникам, которым потребны деньги на обмундировку и для артелей (т.е. совместное, в доле каждого, приобретение продуктов для армейского котла - авт.)» [22, л.25]. Следует отметить, что упомянутые портупей-прапорщики и урядники (а также подпрапорщики), являясь частью командного состава ополчения, тем не менее, не входили в состав собственно офицерского корпуса ополчения. Список необходимых предметов обмундирования и их стоимость были уточнены следующим образом: «Каждому на покупку следующей одежды: холста на 2 рубахи по 7 аршин на каждую за аршин по 30 коп., а за 14 аршин 4 руб. 20 коп., на 2 пары чулок и портянок 2 руб. 50 коп., на полушубок 10 руб., платок на шею 1 руб. 50 коп., сапогов 2 пары 10 руб., ремень с пряжкой 50 коп., рукавицы с варегами 1 руб. 50 коп., ранец на подкладке 10 руб., на шапку вензель 45 коп. Итого: 40 руб. 65 коп. » [23, л.4]. Всего из лиц этой категории пособия получили 87 чел. $[22$, л.34].

26 октября 1812 г. комитет пожертвований нижегородского ополчения «слушал предложения» П.А. Толстого, который, дабы быть в курсе ситуации, потребовал отослать к нему списки «поступивших ... в портупейпрапорщики, подпрапорщики и урядники из дворян и разночинцев и духовного звания людям» с приложением требуемых для них сумм материальной помощи [22, л.37]. Последующая финансовая помощь малоимущим выделялась уже по согласованию Грузинского и комитета пожертвований с Толстым и, по этим договоренностям, с участием уже командующего ополчением III округа, помощь была выделена следующим лицам: в 1-м полку - коллежскому регистратору Бирову; во 2-м полку - подпоручику Н. Пальма и коллежскому регистратору И. Орлову (каждому по 100 руб.) [22, л.39].

Была выделена помощь и группе офицеров, находившимся в личном подчинении Грузинскому и выполнявшими его служебные поручения (они находились в командировках от своих полков при «дежурстве Нижегородского военного ополчения») а именно: адъютанту, титулярному советнику Корепину - 180 руб., губернскому секретарю И. Филимонову - 120 руб., титулярному советнику Денисову - 120 руб., подпоручику Кузнецову - 120 руб., П. Газенкампфу - 180 руб. [22, л.39] (всего всем офицерам при «дежурстве» была оказана помощь на сумму 720 руб.)

По уже утвержденной процедуре согласования Грузинского с Толстым, был выделен новый «транш» помощи как офицерам (пятидесятным начальникам разных полков) - Березовскому, Вернезобру, Тимченко, Мещеринову, Яковлеву, Леонтьеву, Выезжеву, Маврину и Замятнину [24, л.20], сотенным 5-го полка Шебуеву 2-му и Бабанину [24, л.20], а также следующей партии портупейпрапорщиков, подпрапорщиков и урядников «из вольноопределяющихся», поступивших в период с 24 октября по 27 ноября 1812 г., согласно их именному списку [22, л.49]. В декабре 1812 г. были утверждены три новых списка получателей помощи. В списке от 8 декабря 1812 г. значились:

1-го полка:

пятидесятные: «университетские воспитанники»: И. Андреев, В. Топоров, Г. Козявин, И. Пурышев; «Академии студент» А. Виноградов (всем по100 руб.) [22, л.55]; П. Ключарев (получивший 23 руб.48 коп., поскольку он был «произведен» из портупей-прапорщиков в пятидесятные начальники и потому ранее уже получил 76 руб.52 коп.)

подпрапорщик: «недоросль из обер-офицерских детей» А. Ушков (61 руб.52 коп. и 15 руб. «в артель»)

2-го полка:

пятидесятный В. Ястребов (100 руб.)

урядники «из духовного звания»: дьячок И. Сергеев, пономарь С. Гаврилов

4 полк:

пятидесятные: «произведенный из портупей-прапорщиков» П. Андреев и Дадыкин (по 100 руб.)

\section{5 полк:}

урядники «из духовного звания»: дьячок М. Петров; пономари: С. Матвеев, А. Федоров

Конный полк:

урядник: «семеновский мещанин» В. Витушкин [22, 
л.57]

(Всего выдано: 1282 руб.60 коп.)

Список от 15 декабря1812 г. [22, л.59] включал в себя: 1 полк: подпрапорщики: «из обер-офицерских детей» М. Мокеев и «из недорослей из дворян» Ф. Грачев (всем по 61 руб.52 коп.) [22, л.59]

2 полк: урядники «из духовного звания», дьячки М. Петров, Ф. Михайлов [22, л.59]

3 полк: «подканцелярист» С. Пантелеев [22, л.59]

5 полк: «подпрапорщик из обер-офицерских детей» С. Шешунов $[22, \pi .59]$

Конный полк: «урядник вольноопределяющийся казенный крестьянин» М. Афанасьев [22, л.59]

(Всего выдано: 520 руб.64 коп.)

20 декабря 1812 г, уже перед самым выступлением ополчения в поход, были выданы пособия: «подпрапорщику из дворян, недорослю» В. Грачеву (1-й полк) [22, л.60], «подпрапорщику из обер-офицерских детей» А. Мурунову [22, л.60] (5-й полк) и «уряднику из духовного звания, ученику семинарии» М. Вишневскому [22, л.60] на общую сумму 214 руб. 56 коп. Известно также, что много позднее, в мае 1813 г., прошение о материальном «вспоможении» было написано и провиантским чиновником, коллежским асессором Барановым: «... я несу оную службу с крайним отягощением, не имея за собой никакого состояния и без жалованья ... прошу войти в мое состояние и представить о вспоможении мне в сей крайности по примеру прочих дворян ... ибо без оного и службу долее продолжать буду не в состоянии ... » [22, л.61], но конечный результат прошения остался неизвестен.

Материальная помощь офицерам ополчения могла подразумевать не только «прямую» выдачу налич- ности адресного характера: в процессе формирования и действий нижегородского ополчения многие офицеры, ранее служившие «в гражданской службе» (a их в ополчении было большинство), получали, согласно указам Сената, следующие чины (по гражданской же службе) по выслуге лет, либо в силу каких-то особых обстоятельств. Несмотря на то, что они, формально, были уволены с прежней службы, в ополчении действовал «паритет» гражданских и военных чинов, а значит, соответственно возрастал и воинский статус повышаемых в гражданском чине. Новый чин - губернского секретаря - получили: А. Литвинов, А. Павлов, С. Постушенков, Н. Мещеринов, А. Панов [21, л.1-27]; коллежского секретаря - А. Богородский, С. Панов, П. Филисов, Дмитриев [21, л.1-27]; коллежского регистратора - А. Михайлов, П. Пирожков, П. Плешивцов, П. Колосовский, В. Ермолаев [21, л.1-27]; надворного советника - Н. Чичерин [21, л.27]. За «произведение» в новый чин и выдачу нового «патента» (т.е., свидетельства о наличии чина - авт.) со всех перечисленных лиц были вычтены деньги в казенную палату. По поводу вычетов с П. Филисова и П. Плешивцова командир 2-го полка полковник А.П. Ровинский обратился с просьбой к командованию ополчения о постепенных и меньших вычетах с этих офицеров ввиду получаемого ими небольшого жалованья, а именно: «... вычитать только третью часть требуемых с них денег, потому, что по малому жалованью их и по бедности не осталось бы им чем себя содержать ... сделать соразмерный вычет ... » [21, л.27]. Помимо указанных видов материальной помощи, командование ополчения решало вопросы о предоставлении многим семьям офицеров (остающихся в губернии во время военного похода отцов семейств) служебного жилья, об отсрочке выплаты долгов многими из них и пр., что, надо понимать, позитивно влияло как на общий процесс формирования ополчения, так и на морально-психологическую атмосферу, складывающуюся в его командной среде.

\section{ЛИТЕРАТУРА}

1. Грубов В.И., Николаев Д.А. Вопросы архивоведения и источниковедения в высшей школе//Отечественные архивы. 2018. №1. С.116-117

2. Грубов В.И., Николаев Д.А. Вопросы архивоведения и источниковедения в высшей школе//Отечественные архивы. 2019. №2. С.129-131

3. Дорофеев Ф.А., Николаев Д.А. Особенности формирования офицерского корпуса в нижегородском ополчении 1812 г.//Вопросы истории. 2020 . №1. C. $121-128$

4. Дроздов Ф.Б., Николаев Д.А. Народное ополчение 1812 г. и общественный договор//Вестник Нижегородского университета им. Н.И. Лобачевского. 2012. №6 (3). C.95-99

5. Егоров Г.В., Николаев Д.А. Формирование «подвижного магазейна» по снабжению армии в Нижегородской губернии в 1812 г.//Гуманитарные и социально-экономические науки. 2017. №5 (96). С.95-98

6. Кауркин Р.В., Дроздов Ф.Б., Николаев Д.А. Отечественная война 1812 г. Нижегородское ополчение и его участие в заграничных походах $1813-1814$ гг. Н.Новгород: НО ИРИ, 2012. 158 с.

7. Народное ополчение в Отечественной войне 1812 года. Сборник документов /Под ред. Л.Г. Бескровного. М.: Изд-во АН СССР, 1962.548 с.

8. Николаев Д.А. Добровольцы в нижегородском ополчении 1812 г.: исторические реалии и историографические мифы//Вестник Нижегородского университета им. Н.И.Лобачевского.2018. №2. С.67-77

9. Николаев Д.А. Заболеваемость офицеров нижегородского ополчения 1812 г. (по материалам официального делопроизводства начала XIX века)// 
Оборонно-промышленный комплекс России: исторический опыт и современные стратегии. Сборник материалов II Всероссийской научно-практической конференции. 2017. С.96-99

10. Николаев Д.А. Как и чем вооружалось нижегородское ополчение в 1812 году//Военно-исторический журнал. 2019. №2. С.75-79

11. Николаев Д.А. Комплекс документов по вопросам продовольственного и вещевого обеспечения нижегородского ополчения 1812 г.//Торговля, купечество и таможенное дело в России в XVI - XIX вв. Сборник материалов Четвертой международной научной конференции. Редактор-составитель А.И. Раздорский. Редколлегия: В.Н. Беляева [и др.]. 2018. С.345-349

12. Николаев Д.А. Материалы официального делопроизводства по вопросам продовольственного и вещевого обеспечения нижегородского ополчения 1812 г.//Вопросы архивоведения и источниковедения в высшей школе. Сборник статей участников XVI Региональной научно-практической конференции. Под редакцией В.И. Грубова, А.А. Исакова. 2019. С.39-43

13. Николаев Д.А. Некоторые аспекты развития военного производства Нижегородской губернии в начале XIX века (на примере вооружения нижегородского ополчения 1812 г.)//0боронно-промышленный комплекс России: исторический опыт и современные стратегии. Сборник материалов II Всероссийской научно-практической конференции. 2017. С.58-62

14. Хвостова И.А., Николаев Д.А. Инспекторский смотр обмундирования и снаряжения нижегородского ополчения в 1812 г.//Современная наука: актуальные проблемы теории и практики. Серия: Гуманитарные науки. 2017. №12. С.58-61

15. Хвостова И.А., Николаев Д.А. Логистические особенности обеспечения нижегородского ополчения 1812 г. на начальном этапе его формирования (сентябрь - октябрь 1812 г.)//Вопросы истории. 2020. №2. С.217-224

16. Хвостова И.А., Николаев Д.А. Страницы истории нижегородского ополчения 1812 г.: проблема «лишнего» оружия//Современная наука: актуальные проблемы теории и практики. Серия: Гуманитарные науки. 2019. №9. С.35-37

17. Хвостова И.А., Николаев Д.А. «... Упражняются. . . в пьянстве и буйстве. .. »: формирование и девиантные особенности походного марша 3-го полка нижегородского ополчения (сентябрь 1812 - июнь 1813 гг.)//История: факты и символы. 2019. №4 (21). С.27-36

18. Хвостова И.А., Николаев Д.А. Формирование и походный марш 5-го полка нижегородского ополчения 1812 г. (сентябрь 1812 - апрель 1813 гг.)//Гуманитарные и социально экономические науки. 2019. №3 (106). С.98-103

19. Хвостова И.А., Николаев Д.А. Формирование и походный марш конного полка нижегородского ополчения 1812 г. (сентябрь 1812 - февраль 1813 гг.)// Гуманитарные и социально экономические науки. 2018. №2 (99). С.115-119

20. Центральный архив Нижегородской области (ЦАНО), Ф.1822, 0п.1, Д.56

21. ЦАНО, Ф.1822, Оп. 1, Д.75

22. ЦАНО, Ф.1822, ОП.1,Д.86

23. ЦАНО, Ф.1822, ОП.1, Д.116

24. ЦАНО, Ф.1822, Оп.1, Д.125

( ) Николаев Дмитрий Андреевич (dmnikolaeff@mail.ru), Дорофеев Федор Александрович (feddor70@mail.ru).

Журнал «Современная наука: актуальные проблемы теории и практики»

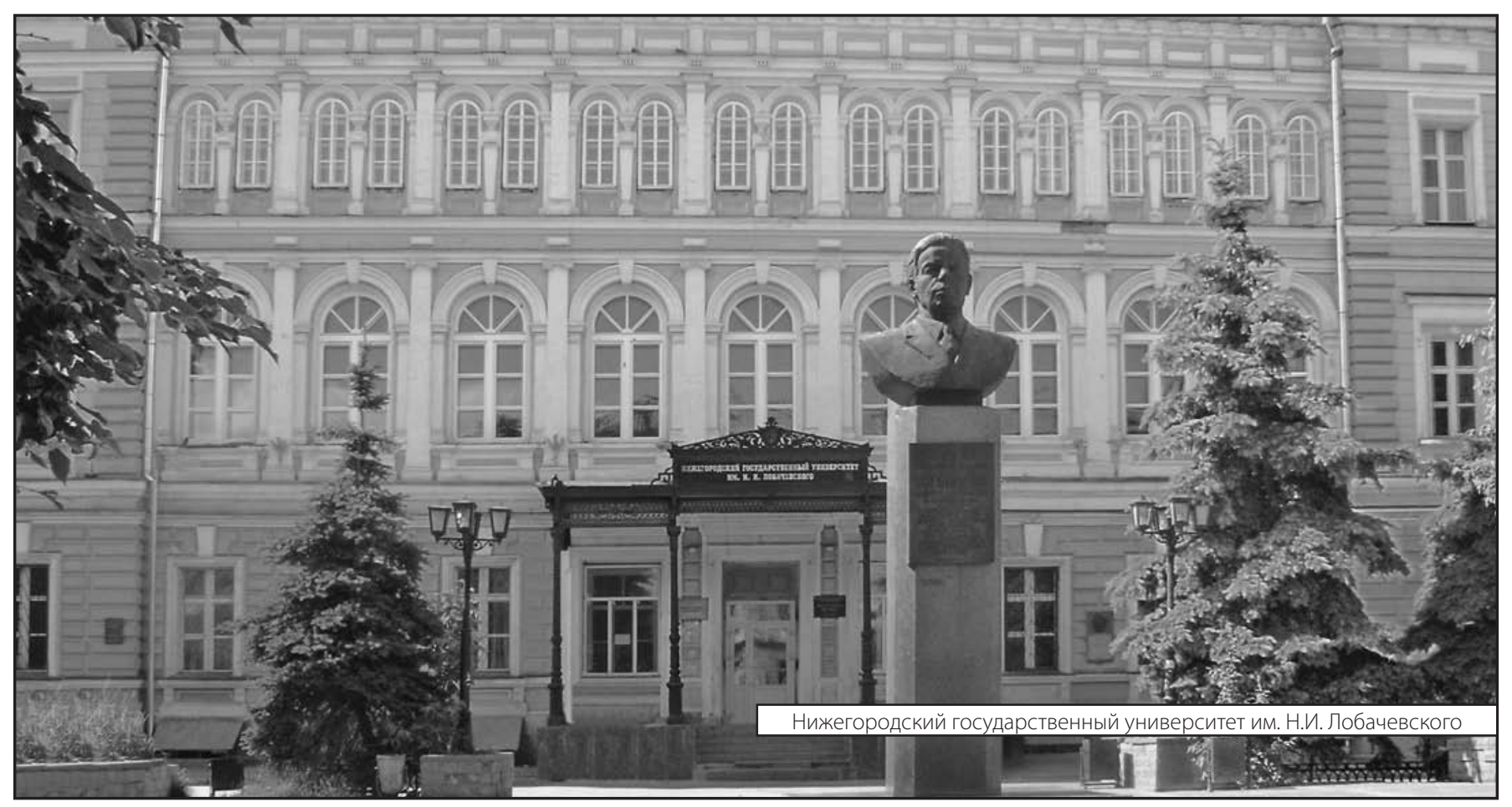

